\title{
Religious Counseling as an Informal Education Approach in Rehabilitation of Drug Addicts
}

\author{
Agoeng Noegroho ${ }^{1}$, Adhi Iman Sulaiman ${ }^{2} \&$ Suryanto $^{3}$ \\ ${ }^{1}$ Master Program of Communication Science, Jenderal Soedirman University, Indonesia \\ ${ }^{2}$ Department of Communication Science, Jenderal Soedirman University, Indonesia \\ ${ }^{3}$ Departement of Public Health, Jenderal Soedirman University, Indonesia \\ Correspondence: Agoeng Noegroho, HR Bunyamin road 993 Purwokerto Central Java 53122, Indonesia. Tel: 62- \\ 8163-529-4. E-mail: riset.88pemberdyaan@gmail.com
}

Received: October 16, 2018; Accepted: October 28, 2018; Published: October 31, 2018

\begin{abstract}
Drug abuse has become a problem and a threat to development, especially human development and the younger generation. The research aims to describe and analyze religious counseling as an informal education approach in the rehabilitation of drug addicts. This study uses a qualitative case study method,that selects informants by purposive sampling, i.e. the management of foundation, religious counselor and drug addicts. The data was collected through interviews, observation and documentation with interactional analysis. The research is located at An-Nur and Nurul Ichsan Al Islami foundation in Purbalingga Regency, Central Java. The result showed that prevention and rehabilitation of drug abuse has not only been supported by law enforcement, medical and psychological rehabilitation, but also by social, herbal and spiritual rehabilitation through religious counseling as an informal education approach. The religious counseling as an informal education approach is an effective rehabilitation through prayer, dhikr, recitation, rukyah, spiritual cleansing, natural cultivation, religious tourism and herbal therapies are aimed to prevent drug dependence that damages both physically and mentally. Then the process is continued by reinforcing faith and devotion, returning human identity that is always worshiping, doing good, preventing badness and bcoming e a blessing for all nature.
\end{abstract}

Keywords: drug addicts, herbs, human resources, informal education, religious counseling

\section{Introduction}

The development that aims to create and improve fair and equitable prosperity, in the context of the development of human resources, has challenges, obstacles and threats, one of them is drug abuse that can damage psychology, motivation, creativity, productivity and individual morality, even further threatening national development and resilience. The importance of human resources in development is not only determined by natural resources and progress in infrastructure and the economy, but also determined by the quality of life that is physicaly and spiritualy healthy. According to Notoatmodjo (2008) the nation's main assets include natural resources and human resources, however, human resources play a more decisive role because of their role in managing natural resources. Widodo (2011) stated that the essence of development is human development, so that the priority of spending in order to improve human development will also increase the level of community welfare.

Based on the Indonesian National Narcotics Agency of Press Release in 2016 drug abuse and illicit trafficking are extraordinary crimes that threaten the world and can be used as a weapon in a proxy war to paralyze the nation's power. Therefore, this crime must be eradicated and handled comprehensively. According to Komjen Pol Budi Waseso, the Head of the Indonesian National Narcotics Agency, this crime has been included in the emergency danger of drugs. In June 2015 there were 4.2 million and in November increased significantly to 5.9 million. Reports from the National Narcotics Agency in the 2014-2015 edition states that the number of narcotics misuse from the elementary-high school level is 4,027 students, the number of suspects secured by the National Narcotics Agency is 28 from the 16-24 year age group. It is very ironic that 181 others have a junior-high school education background. In Central Java the number of prisoners of narcotics cases in 2013 amounted to 3,237 people consisting of 2,281 dealers, and 956 drug users. Whereas in Purbalingga Regency, as many as 39 drug addicts have received rehabilitation therapy services at rehabilitation facility. 
The number of narcotics, psychotropic substances and addictive substances users among teenagers tends to increase. The danger of losing a productive generation is visualized before the eyes. Users of narcotics, psychotropic substances and addictive substances (drugs) are estimated to be around 5 million people or $2.8 \%$ of the total population of Indonesia. Teenager users aged 12-21 years are estimated at around 14,000 people from the number of teenagers in Indonesia around 70 million people.

According to the explanation in Law Number 35 of 2009 concerning Narcotics, Narcotics is a substance or drug that is very useful and needed for the treatment of certain diseases. However, if it is misused or used not in accordance with the standard of treatment, it can have a very detrimental effect on individuals or communities, especially the young generation. This will be more detrimental if it is accompanied by the abuse and illicit trafficking of narcotics which can lead to greater harm to the life and cultural values of the nation which will ultimately weaken national resilience. Then in reality narcotics crime in the community shows an increasing tendency both quantitatively and qualitatively with widespread victims, especially among students, adolescents, and the young generation in general.

Human resource problem is caused by drug abuse, especially teenagers that are targeted as nation's generation (Darokah \& Safaria 2005). According to Hawari (2006) drug users will have dependency, their lives experience mental disorders and are no longer able to act properly in society such as damage to social functions, work, school, and unable to control themselves. According to Martono and Joewana (2008) the young generation is the most potential target of the drug trafficking mafia, so they are very vulnerable to these problems.

Because adolescence is a time of self-discovery, both thoughts, attitudes and behavior are easily influenced by the family environment, peers, friends, and school (Hermawan \& Santosa 2013). In the era of communication technology and information media through the internet that has been easily accessed or obtained, teenagers will be affected quickly by the process of interaction. According to Sulaiman (2011) teenagers or students interpret internet media as entertainment media, interaction media and science media, so that students assess the internet media more positively. But teenagers are also aware of the negative effects of internet media such as pornography in the form of pictures and videos, as well as violence act through online game, the impact of being dependent, forgetting time, and spending time studying.

Based on the Data and Information Research Center (2016) the level of knowledge of Drugs in individual that knows the danger of narcotics is quite good, but understanding in drug prevention is still low. So it is necessary to make a counseling, education, and information that is maximized, especially in the strengthening aspect of effective prevention from the threat of drugs. Facing drug abuse is not only by strict eradication and law enforcement, there are also prevention efforts through community empowerment and rehabilitation as according to the implementation of national policies and strategies for the prevention and eradication of drug abuse and illicit trafficking in 2011-2015 covering fields of (1) prevention, (2) community empowerment, (3) rehabilitation, and (4) eradication.

Rehabilitation for drug addicts in Law No. 35 of 2009 concerning Narcotics, in Article 1 Paragraph (16) Medical Rehabilitation is an integrated treatment process to free addicts from Narcotics dependence. Paragraph (17) Social Rehabilitation is a process of recovery activities in an integrated manner, both physically, mentally and socially, so that former Narcotics addicts can return to carry out social functions in people's lives.

Medical and social rehabilitation can be supported and supplemented by religious counseling as an approach to informal psychology education to restore mental health. Religious counseling is an approach of informal education and religious therapy that has meaning and wisdom about morality to restore human nature, as according to Hamid and Ahmad (2013), talent consists of cognitive competence, affection and connotation, based instinct and lust drive that are positive (easy), and intuition that is conscience. Pransiska (2016) thinks that human nature is divided into three, namely the nature of religion, pure nature, and intellectual nature. According to Anwar (2014) psychopathology in Islam is worldly in the form of psychiatric symptoms in contemporary psychology, while psychopathology is ukhrawi, in the form of illness due to deviations from moral, spiritual and religious norms or values. Based on this, the author has an interest in researching the model of religious counseling as an informal education approach in the rehabilitation of drug addicts at the An-Nur Foundation and Nurul Ichsan Al Islami Foundation in Purbalingga District, Central Java. The study was carried out in 2017, using a qualitative case study method, the selection of informants with purposive sampling, namely the leadership of the foundation, religious counselor or drug addicts and addicts. Data is collected through in-depth interviews, observation and documentation with analysis of research data using interactional analysis, namely collecting data, reducing data and drawing conclusions. 


\section{Method}

The study used qualitative methods with case studies, it not enough if the Case Study question only asks "what", but also how and why. The what question is intended to obtain descriptive knowledge, how question to obtain explanative knowledge, and why question to obtain exploratory knowledge (Yin 2013).

The location of the study was determined based on the results of the preliminary hearing and recommendations from Narcotics Agency of Purbalingga regency namely Islamic Education Foundation Nurul Ichsan Al Islami in Karangsari Village, Kalimanah District and An-Nur Foundation in Bobotsari in Purbalingga. The research used purposive sampling by selecting informants, namely the chairman and management of the foundation, the former drug addicts that were in the process of rehabilitation of psychology, mental, medical / health and assistants such as Social Workers, Addiction Counselors, and Volunteer Counselors.

The research data was collected by distributing questionnaires, in-depth interviews, direct observation, and Focus Group Discussion (FGD). Qualitative Analysis with an interactive model of Miles and Huberman (2007) consists of three main things: (1) Data reduction that is the process of selecting, focusing, simplifying and classifying raw data that arises from written records in the field, which take place continuously during the study. (2) Presentation of data that is a compiled collection of information that gives the possibility of drawing conclusions and taking action. (3) drawing conclusions or verification, after the data is collected, then analyzed qualitatively starting from searching, recording the order, patterns, explanations, complete configuration, so that conclusions are verified during the study.

\section{Results and Discussion}

\subsection{Drug Rehabilitation}

There is a case of Drug Rehabilitation in Purbalingga Regency, Central Java, which is addressed by the Narcotics Agency of Purbalingga regency. There is also an alternative rehabilitation by rehabilitation institutions that have existed and have played a long role in the community long before stood. The foundation in question is the Islamic Education Foundation Nurul Ichsan Al Islami in Karangsari Village, Kalimanah District and An-Nur Foundation in Bobotsari in Purbalingga, the two foundations initially deal with addicts who experience mental disorders.

Narcotics Agency of Purbalingga regency handles rehabilitation for drug addicts by providing recommendations for medical rehabilitation that have been scientifically accountable for medicine. Recommended rehabilitation place is for outpatient care at the Regional General Hospital dr. R. Goeteng Taroenadibrata in Purbalingga regency and for treatment at Ghrhasia Mental Hospital, Sleman regency of Yogyakarta province. However, according to the prevention and eradication section of Narcotics Agency of Purbalingga regency there are still major problems that remain obstacles in rehabilitation, namely: (1) Addicts deliberately continue to follow the medical rehabilitation process only to get free medicines as an addition, so the rules for reducing the dose of drug addiction are unsuccessful and addicts remain addicted to drugs. (2) There are still drug addicts and pharmacies who abuse licenses to use drugs prescribed by doctors, and can even be a source of drug transactions. (3) Drug addicts have a mode of wanting to rehabilitate their hospital stay, which is recommended to protect themselves from lawsuits, refuses to provide important information about the source of narcotics and secures the drug distribution network. (4) Addicts that take care of those who continue to operationalize the distribution network where there is less supervision.

Therefore the Narcotics Agency of Purbalingga regency provides recommendations to better guarantee the rehabilitation process in a selective, comprehensive and rigorous manner so that drug addicts can achieve recovery, treated at the Narcotics Rehabilitation Center, Lido, Bogor regency, West Java. As for rehabilitation carried out by institutions or community-owned institutions such as the An-Nur Foundation and Nurul Ichsan Al Islami in Purbalingga, the Narcotics Agency of Purbalingga regency does not recommend because (1) Based on the structure and function of the Narcotics Agency of Purbalinggga regency in the rehabilitation process must coordinate with a hospital that has been officially appointed. (2) Assessment of rehabilitation in institutions / foundations managed by the community with non-medical processes through herbs and religious rituals do not have medical standards that are scientifically accountable. But Narcotics Agency of Purbalinggga regency always cooperates with the foundation in treating the rehabilitation process, a campaign program for the formation of anti-narcotics cadres, campaigns of drug abuse danger and the empowerment of drug addicts. (3) Both rehabilitation institutions are under the coordination of the Ministry of Social Affairs so that they are assisted by religious counselor / facilitators, namely Social Workers, financial assistance for rehabilitation programs.

An-Nur Drug Rehabilitation Foundation and Nurul Ichsan Al Islami in Purbalingga have another perspective on drug rehabilitation, namely (1) Drug addicts without medical rehabilitation can be done on condition that addicts 
have strong intentions and determination to recover and want to stay overnight in rehabilitation centers with a humanist, family and religious approach. (2) Religious reaction can be overcome with an open religious approach and dialogue (religious counseling as an informal education approach) to touch the heart in healing disorientation, frustration and discreditation, then religious therapy with the obligation to pray, dhikr tauhid, spiritual cleansing, recitation, and sholawatan to create and increase faith and devotion as the ummah. (3) The rehabilitation process can be carried out socially with environmental therapy for the cultivation of nature, which is one with nature to understand and reflect the meaning of natural beauty created by God. (4) The family approach for drug addicts with open dialogue is more effective in eliminating closed attitudes, fear, worry and isolation (asocial).

Rehabilitation perspectives are similar between Narcotics Agency of Purbalingga regency and the foundation of An-Nur institution and Nurul Ichsan Al Islami for drug addicts, namely (1) Individuals who are trapped into drug addicts are victims who must be immediately helped, got attention and rehabilitation treatment to achieve recovery and no longer trapped by Drugs. Drug addicts who have the status of distributors as suspects still have to face the consequences of legal sanctions, but the rehabilitation process is also given. (2) The motive behind the fall of narcotics is generally caused by disharmony or family conflict so that lack of attention, affection and eventually escape to drugs. Then the strength of faith and mentality is fragile. They want to try or invited by friends, negative environmental influences and miscommunication. (3) the biggest factor to be able to recover or no longer be caught in drugs is the strong will and determination of the addict himself to recover and not return to drug abuse, the environment and friends who plunged him. (4) Drug addicts are very difficult to be able to recover completely, thus they require the process of religious counseling as an approach to informal education or assistance, empowering the potential to be cured and independent and can be re-accepted and socialized with family or community.

According to Klonaris et al. (2007); Padmiati and Kuntari (2011) someone uses drugs because of the desire to experiment, escape from stress, to have fun, or for the socialization and existence of group recognition. Rahmadona and Agustin (2014) state that drug abuse is due to the low level of religiosity, the lack of family and environment role, and the influence of negative social relations. Anggreni explained that there are factors of drug abuse, namely anti-social personality, psychological conditions that easily feel disappointed or depressed, family problems, peer groups, and easy to get drugs, social factors with the environment or relationships. Research results from Platt (1995) and Lindesmith (2017) the reason for using drugs for the first time is to try, invited by friends, family problems, family environment and friendship, being forced, to have fun, stress (pressure problems), easily obtained or purchased.

\subsection{The Role of Civil Society Institutions in the Rehabilitation of Drug Addicts}

There are two Islamic foundations in Purbalingga, Central Java, which are engaged in social and rehabilitation of drug addicts, namely the Nurul Ichsan Al Islami Foundation and the An-Nur Foundation. The foundations are very helpful, especially Narcotics Agency of Purbalingga regency and the general public at large in the prevention and rehabilitation of drug addicts, including the designated hospitals responsible for conducting medical rehabilitation. The uniqueness of the two rehabilitation institutions is an alternative for the family and drug addicts not only to find rehabilitation places that can avoid addiction and the danger of environmental influences, but also can receive rehabilitation in a non-medical and religious manner with a religious approach to build good faith and good morality. Many drug addicts who have been rehabilitated in the two foundations come from outside the region and outside Java, this is because the drug family and addicts are more comfortable and protected from negative stigma and social sanctions in their communities. The two foundations at the beginning were rehabilitation centers for addicts affected by mental disorders, stress, and depression.

Prevention and rehabilitation of drug abuse should be carried out by all parties to play a role and work together, not only the National Narcotics Agency and the Ministry of Social Affairs or the government, but also the wider community, social and educational institutions. The existence and role of the An-Nur Foundation and Nurul Ichsan Al Islami that carry out rehabilitation through religious counseling as an approach to informal education and religious therapy for drug addicts are very important and useful to assist the prevention and rehabilitation of the government in this case the Indonesian National Narcotics Agency and the Ministry of Social Affairs. According to Muhtar (2005); Babaie and Razeghi (2013) that drug abuse has spread widely in the community, it requires synergy in handling it by the stakeholders of government institutions, non-governmental organizations, and the private sector as the main pillars in the current development paradigm. Although the government has programs and budgets in the prevention and rehabilitation of drug abuse, it still requires awareness and active participation from the community with all its potential such as realizing community based social rehabilitation. 
The following is a profile description and role of the two rehabilitation foundations based on the results of interviews, observation and documentation analysis, namely: (1) An-Nur Foundation located in Bungkanel Village, Karanganyar District, Purbalingga Regency, was established on August 28, 1995. The An-Nur Foundation has a vision that is the realization of professional mental health services and oriented to customer satisfaction. Its missions are (a) realizing a financial management system and manage resources efficiently, transparently and accountably. (b) providing and developing education, training and research facilities in the field of mental health services to improve the quality of human resources. (c) seeking professional service oriented to customer satisfaction. (d) developing hospital facilities and infrastructure. (e) providing services to customers sincerely.

The foundation has emergency installation facilities, inpatient installations by providing room class facilities and outpatient installations to service child and adolescent growth, adult mental health services, elderly mental health services, organic mental disorders services, drug dependence services, community mental health services, and religious counseling as an approach to informal psychotherapy education and psychology. The number of addicts taking care in 2017 is between 80 and 90 people and outpatients are generally 200 people.

The uniqueness of the An-Nur Foundation is a mixed drug rehabilitation institution that is medical in nature with treatment and health facilities as mental hospitals that have medical doctors, and non-medical with a spiritual approach or religious counseling as an informal education approach. Sometimes a lot of addicts are brought by their families on the grounds of being mentally disturbed, but in reality they have become drug addicts. This happens because the assumption of drug addict families that feel more embarrassed if they are known as drug addicts compared to mental illness.

The Nurul Ichsan Al-Islami Foundation was established by Achmad Ichsan Maulana who was also the leader, at the beginning in 2000 it was a boarding school, in 2007 became a drug rehabilitation center. The uniqueness of the rehabilitation process for drug addicts at the Nurul Ichsan Al Islami Foundation is non-medical by using herbal media and religious therapy, so it does not use medical drugs at all. Then drug addicts are required to stay overnight with a minimum standard of 40 days following the rehabilitation process and should not be seen by family and friends. The number of drug addicts is generally around 30 to 60 people in a year, many from outside the city. According to Keen et al (2002); Winkelman (2003); Ali (2014) one of the objectives of the rehabilitation program is to restore the biopsychosocial condition so that it can return to life in the community, able to solve social problems experienced, able to meet the needs and be able to carry out social roles, independently and normatively. Corey (2000) stated that religious counseling approach as an informal education approach with humanistic existential theory that has positive basic aspects of the individual, namely the capacity of self-awareness, freedom and responsibility, creating self-identity and constructing meaningful relationships with others, seeking meaning, goals, values and goals, experiencing anxiety, aware of the end in life (death).

\subsection{Approach to Religious Counseling as an Informal Education Approach in the Rehabilitation of Drug Addicts}

Religious counseling as an approach to informal education and religious therapy as rehabilitation of drug addicts is a communication process between religious counselor or companions with addicts or drug addicts. The process and practice of counseling is the embodiment of one of human perfection that is given the feeling (heart), mind and senses starting from hearing, sight and pronunciation (sounds and words).

According to Hefni (2014) counseling has been given by God since the first human being was created with the most important counseling tools, namely hearing, sight, and heart, one of the functions of counseling is that humans need friends to counsel, to share feelings and to get peace of life.

Religious counseling as an approach to informal education and religious therapy is an alternative in the rehabilitation of drug abuse in addition to medical treatment is done and recommended by the National Narcotics Agency. Religious counseling as an informal education approach can complement the process of rehabilitation with religious counseling as an approach to informal medical and psychological education, so it is important for drug addicts. Erhamwilda (2009) explained that the guidance of religious counseling as an approach to Islamic informal education is the process of providing assistance continuously and systematically to individuals or groups of people who are experiencing mental and physical difficulties to be able to understand themselves and be able to solve problems, so that they can live in harmony in accordance with the provisions and instructions of God and His Messenger in order to achieve the happiness of the world and the hereafter.

According to Kibtyah (2015) and Rahmawati (2016) religious counseling as an informal education approach is a branch of psychology with the practice of giving assistance to others which is also known as counseling, in the form of information, advice, explanation and support. Religious counseling activities as an informal education approach not only has a relationship between religious counselor and clients but also can involve more than two people in order to understand life so that they can find solutions to the problems faced by clients and provide 
information and various alternative solutions provided by religious counselor. Falah (2016) states religious counseling as an approach to informal education as an activity between two individuals or more. It is expected to change one's views and behavior. The success of religious counselor is evidenced by the understanding and practice of religious counseling as an informal education approach that sees piety not only to revolve around the success of the afterlife, but also in the management of the world so that people can develop a life of grace, dignity and justice.

The process of religious counseling as an approach of informal education and religious therapy is a rehabilitation of drug addicts after the addiction phase is recovered, then empowerment programs are given in the form of counseling, comparative studies, training and mentoring to develop and establish economic business groups based on interest, as well as talent or potential of drug addicts. Provision of skills, abilities and high motivation for economic entrepreneurship can be used as a medium to be accepted again and socialize with family and community, then can create independence and prosperity. Research result Padmiati dan Kuntari (2011) showed that community empowerment model in the prevention of drug abuse by forming a Community-Based Rehabilitation Forum was successfully implemented the three divisions formed, namely the socialization, referral and religious counseling divisions as an informal education approach, advocacy and further guidance in carrying out jointly planned work programs. Sulaiman (2013) stated empowerment focuses on identifying problems faced and potentials such as human, social, economic, cultural and environmental resources by providing opportunities to develop themselves or develop towards independence towards better change.

Based on press release of Indonesian National Narcotics Agency 2016 that conducts community empowerment activities in the form of counseling and skills training that aims to explore the potential of the community, especially those in narcotics-prone areas, to produce independent individuals who have a good work ethic so that they no longer make narcotics as a business choice to continue their lives.

The rehabilitation process of drug addicts between An-Nur Foundation and Nurul Ichsan Al Islami Foundation has similarities, namely (1) approach, practice and religious counseling as an informal education approach to restore human fitro which has monotheism, faith and devotion. Then all activities of life are doing good and preventing munkar and becoming human beings who bring mercy to the environment or the whole of nature. (2) The rehabilitation process with religious counseling is an approach to informal education through religious rituals to re-establish direct worship to God such as five-day prayer, sunnah prayer, dhikr, and recitation. Then worship with intermediaries (ghoirmahdhoh) such as interacting through recitation, lectures, night contemplation, natural cultivation, and religious tourism. (3) healing the mentality is determined by God but the key must begin with a strong intention and determination in the drug addict and beng fear of sin, a negative impact that can damage him both health, mind, mental, family and community.

The difference in the rehabilitation process at the An-Nur Foundation is mixed, medically and non-medically (religious approach) with the principle that there are three elements that are inseparable, namely, scientific by carrying out medical procedures in dealing with addicts, so that there is a health check or diagnosis, laboratory, and medical treatment. Second, it is natural to use a natural environment that is beautiful, clean, healthy and beautiful as a medium of therapy or rehabilitation by utilizing the existence of places and environments around the institution and bringing addicts to the location of natural attractions. Third, it is Divine in nature, which is to conduct a religious counseling approach as an informal education approach through religious rituals such as prayer, dhikr and spiritual splashing.

Based on the results of interviews and observations, the rehabilitation process of the An-Nur Foundation uses the Divine element as a model of religious counseling as the following informal education approaches: (1) Performing Prayers and dhikr by considering the condition of addicts, if he/she is still considered to have unstable mental disorder, then drug addict patient is isolated in they own room with special guidance. Addicts who have been judged to have good enough conditions, pray in congregation. The prayer activities are also carried out to continue to purify and draw closer to God, such as qabliyah and ba'diyah prayers, birrul walidain prayers and shalat. Especially for birrul walidain prayers are usually done on Friday night keliwon. Prayers and Dhikr are done after prayer and praying together as religious media function to get closer to God, always remember the greatness of God, the request of forgiveness for sin and reassurance. (2) Rukyah is held twice a week, that is on Wednesday night and Friday night, then once a month on Friday night Kliwon. Rukyah was carried out led directly by Supono Mustajab who was followed by addicts and their families, Islamic religious leaders and the general public. The rukyah process begins after Isha prayer in congregation, Ba'diyah prayer Isya, recitation of dhikr after prayer, and giving tausiah, then the process of rukyah begins with prayer readings together. Special for prayer therapy at Kliwon night, the procces starts at night. 
Then it is continued by tausiah from several scholars and closed with prayer. Religious therapy is carried out through drinking water with prayer and prayer therapy given to addicts. Addicts must have the trust and confidence that prayer water is a medium of religious counseling as an informal education approach to distribute the power of prayer to complement the struggle that provides healing and rejects evil.

While the Nurul Ichsan Al Islami Foundation has the concept of rehabilitation with a religious counseling approach as a purely informal (non-medical) approach to education, and supported by herbs both drinks, food and rituals of the healing process with prayer, dhikr, prayer and spiritual cleansing. All medical elements such as medicines and medical diagnoses are not medically done. But the foundation does not close itself to medical counseling and checking such as from the faculty of health and medicine.

Missions of drug rehabilitation on Nurul Ichsan Al Islami are fortifying the mindset of abandoned children and being able to avoid narcotics. It also deepens Islam in accordance with the teachings of the holy book to victims of Narcotics abuse. In addition it deepens the religion of Islam in accordance with the teachings of the Koran to neglected and underprivileged children and society in general.

Narcotics rehabilitation model of Nurul Ichsan Al Islami foundation, are (1) religious counseling as an approach to informal education with family approach and friendship between religious counselor or companions to drug addicts, So that the creation of closeness, dialogue, openness and mutual understanding, result in self-identification or the motive of the background and purpose of falling drug. Religious counseling as an informal education approach is carried out at any time by looking at the situation and condition of addicts, the aim is to foster a sense of trust, openness, closeness and willingness to share stories, knowing the motives of falling drugs, the problems faced and desirable expectations. Then if the phase has been created, it will gradually provide religious counseling as a reiligious and informal education approach so that addicts have more faith and confidence on the basis of religion. (2) Conducting religious counseling as an informal education approach through the concept of the family (parents) starting from pregnancy, giving birth to raising children. The concept of heaven is under the feet of the mother, and the father who earns a living and family members who love each other. This is to reconstruct positive cognitions, affections and connotations or reorganize self-management. (3) Herbal media is to rehabilitate addicts who are addicted to Narcotics by given a drink of herbal ingredients such as young coconut water, turmeric, honey wasp, cardamom, wulung betel leaf and Ajwa dates. The ingredients are mixed into drinks such as herbal medicine whose properties are to treat addicts who experience sakau or addiction, restore stamina, vitality and body immunity. (4) Religious therapy is done through congregational prayers and dhikr on the night after Maghrib and Isa prayers. Then the spiritual splash with recitation or tausiah from the leadership of Yayaan Achmad Ichsan Maulana with dialogical and interactive methods as a medium of religious therapy. The goal is that there is a diversion of attention, thoughts and addictive activities from drug addiction to remember more about the greatness of God, repentance for sins that have been committed, returning human nature to worship and doing good. (5) Rukyah with boiled or boiled therapy is a method of treatment of boiling the addicts of Narcotics into the barrelshaped bath with a diameter of $120 \mathrm{~cm}$ and a height of $60 \mathrm{~cm}$ filled with boiled water and given the concoction of guava leaves, bay leaves, kamijara leaves, yeast and 1 bucket of water that has been given a prayer. Addicts enter the barrel in a sitting position with water limited to the chest of an addict. Boiling time for addicts for 10 to 25 minutes. Boiled therapy is carried out after maghrib until night. Addicts who have been boiled are prohibited from taking regular water baths, so that Narcotics poisons in the body come out of the pores of the skin in the form of colored sweat. The red sweat signifies addicts to marijuana and the white one indicates addicts to shabu and heroin users or the like. (6) Rukyah with night bath therapy, namely treatment is carried out by narcotics addicts bathing at the meeting place of three rivers in the Klawing river, Kaligintung river and Kalibanjaran river in Purbalingga at midnight Tuesday and Friday. The benefits to addicts are fighting sakau with the cold water of the river and facilitating oxygen intake in the natural environment around the river. The purpose of night bath therapy as a religious medium is to get closer and acknowledge the greatness of God and increase equality. (7) Environmental therapy by visiting the location of natural attractions such as mountains, hills, rivers, waterfalls, swimming pools, and beaches as a medium of religious therapy to get closer and strengthen faith in God through his creation that is nature, then to entertain and adapt to the community environment so as to reduce the feeling of being isolated from the general public, to increase togetherness, cohesiveness and hope together.

The difference in rehabilitation of drug addicts at the An-Nur Foundation and Nurul Ichsan Al Islami, is the rehabilitation process at An-Nur is a combination of medical approaches as mental and non-medical or herbal and spiritual hospitals. While Nurul Ichsan Al Islami used a religious counseling approach as an approach to informal education and religious therapy as well as spiritual (non-medical) herbs. The second equation is the use of religious counseling as an approach to informal education and religious therapy, then the An-Nur Foundation was once a 
Report Obligatory Receiver Institution for Drug Addicts with permission, funding and escort from the Ministry of Social Affairs in 2012 to 2014, while Nurul Ichsan Al Islami Foundation from 2015 to 2017.

According to Irfangi (2015) and Zulamri (2017) functions of religious counseling as an approach to informal education of Islamic psychotherapy in the treatment process and healing of mental, spiritual, moral and physical disorders or victims of drug abuse, are understanding, control functions, prediction functions, development functions; function of education, prevention, healing and treatment functions, sterilization function, and purification function.

There are similarities in rehabilitation through religious counseling as an approach to informal education and religious therapy conducted by the An-Nur Foundation and Nurul Ichsan Al Islami with three Islamic guidance formats for drug addicts according to Ali's research, namely: (1) Classical format through religious lectures, education manners, and worship together. (2) Format groups through group guidance activities (religious material). (3) Individual format through a consultation process for addicts and families of addicts. Risdawati (2014) affirmed the efforts of religious guidance and counseling as an approach to Islamic informal education is to help individuals realize themselves to be fully human in order to achieve happiness in the world and the hereafter through a wisdom or wise approach and want to recite hasanah that is giving advice to multiply the remembrance of God like remembrance and prayer.

Differences and equality of rehabilitation can be presented in the religious counseling model as an approach to informal education and religious therapy presented in Figures 1 and 2.

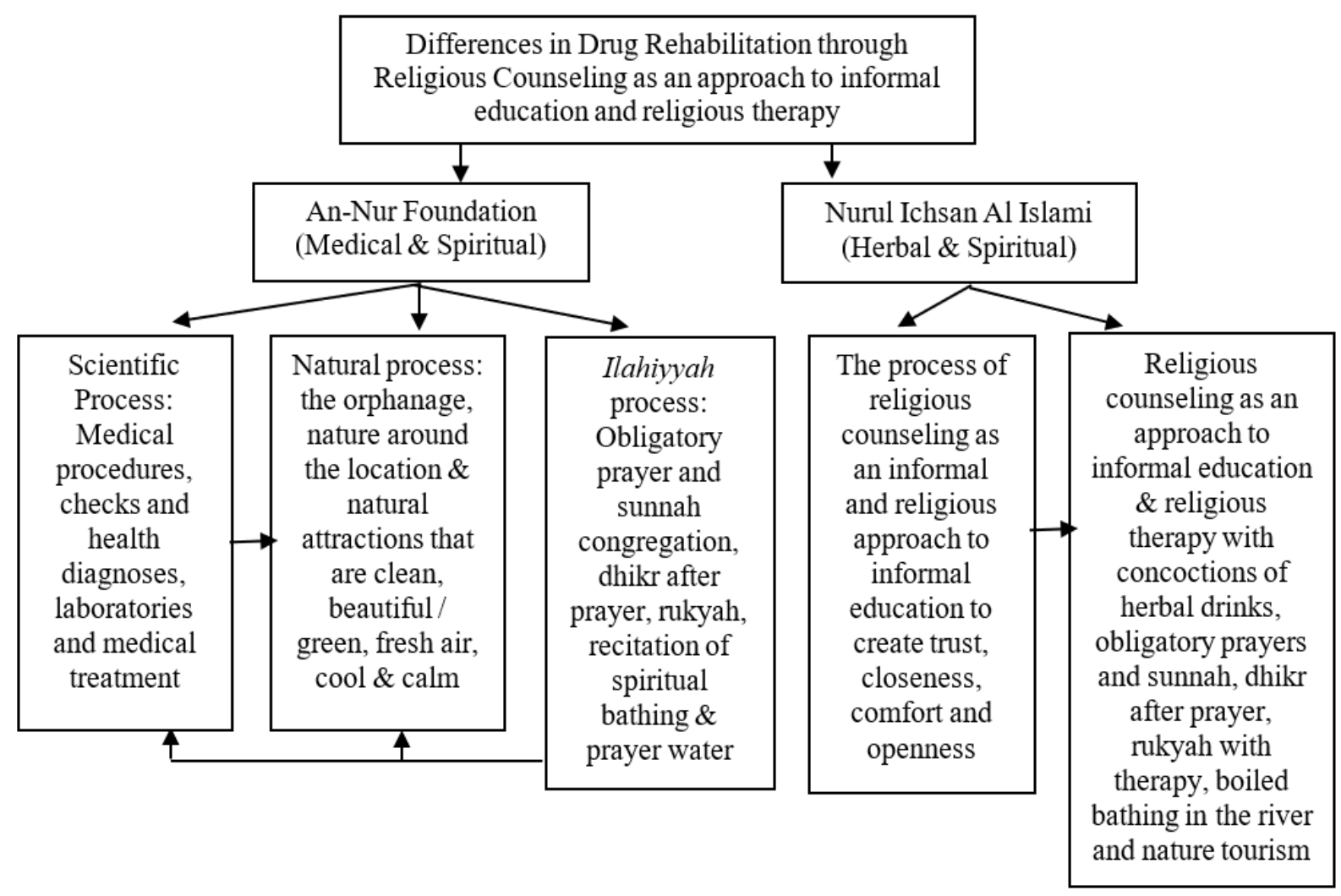

Figure 1. Differences in religious counseling as an educational approach informal dan Terapi Religi Pecandu Narkoba 


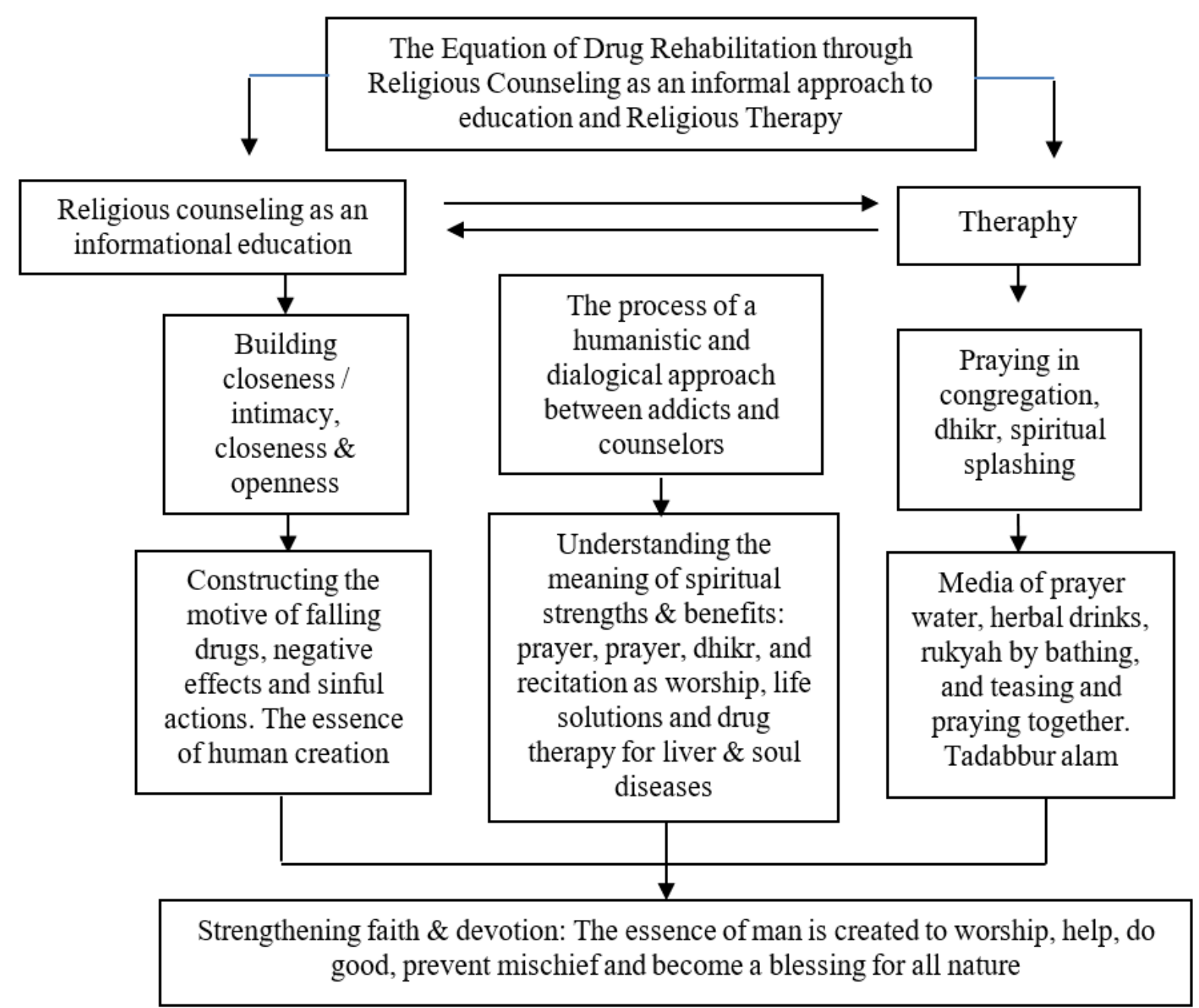

Figure 2. Equation Religious counseling as an approach to informal education and religious therapycandu Narkoba

The difference in rehabilitation between the An-Nur Foundation and Nurul Ichsan Al Islami is a complementary alternative to the recovery process for drug addicts. Medical rehabilitation is needed to identify and diagnose physical health, then rehabilitation psychologically and non-medical through religious counseling as an approach to informal education and religious (spiritual) therapy can identify the motives of the causes and objectives of drug abuse, improve the mindset, moral, mental and drug addict behavior. The recommended rehabilitation standards are conducted medically because they can be scientifically accountable, but have weaknesses, including the presence of drug addicts who have no intention to recover and are still addicted to use drugs that are allowed to continue to be consumed, either drug addicts of outpatient or stay in care. Drug addicts cannot be completely cured so they have the potential to re-abuse drugs.

The rehabilitation phase of drug abuse through non-medical such as religious counseling as an approach to informal education and religious therapy becomes an alternative that can complement each other and can be collaborated, because the negative impact of drug abuse is not only physical health, but also psychological, mental and moral disruption. As a result of Alie's research, rehabilitation programs can be carried out in an integrated form between religious values, medical and social actions to complement each other. Spiritual capital (Islamic) has the function of being a guardian of the effects of irregularities. There is rehabilitation of drug abuse scientificbased approaches (health, psychology, social work and others) and a spiritual (religious) based approach. The results showed the relationship between the level of religiosity and drug abuse behavior, namely the higher the level of religiosity, the lower the individual's drug abuse. 


\section{Conclusion}

Drug abuse is generally caused by family problems, mental disorders of a weak personality, losing by problems, stress, and frustration. It is affected by the environment of bad social interaction, the influence of friendship, want to experiment and be recognized its existence.

The drug prevention and rehabilitation process is a shared responsibility between family, relatives, close friends, Narcotics Agency of Purbalingga regency, social, educational and religious institutions that can help each other and work together to save the nation's generation from the dangers of drug abuse.

The An-Nur Foundation and Nurul Ichsan Al Islami Foundation become social, educational and religious therapy institutions that can support and become drug abuse prevention agents and rehabilitation of drug addicts. Danger prevention of drug abuse is not only repressive with strict law enforcement, but also requires prevention with counseling programs or socialization, especially among students in junior high schools, high schools, students, families and social institutions.

The rehabilitation of drug addicts will succeed if there is a strong intention, their own willingness to recover and no longer want to fall into drug abuse and support or concern for families, relatives, and close friends.

Rehabilitation of drug abuse cannot be solved by a medical approach but must be supported by religious counseling as an approach to informal education and psychological and non-medical therapies such as herbal and spiritual.

Religious counseling as an approach to informal education and religious therapy for drug addicts is done through a dialogical humanitic approach and eliminates the distance between religious counselor or companions with addicts to build closeness, openness and equality that is strengthened by human nature created to worship, help each other, do good and prevent evil and become a blessing for all nature.The superiority of religious counseling as an approach to informal education and religious therapy for drug addicts is to avoid dependence on medical or chemical drugs that can damage organs, restore human fitro always to remember the greatness of God, human nature is created to worship, do good and prevent evil and to be a blessing for all nature, to foster a sense of togetherness, solidarity, mutual motivation and life expectancy to change for the better.

Drug addicts who can recover with religious counseling proces as an informal education approach and religious therapy can be counselors who help other religious counselor such as social workers and psychologists in conducting drug abuse rehabilitation.

Medical, psychological and non-medical rehabilitation through religious counseling as an approach to informal education and religious therapy are complementary alternatives and can be collaborated in the recovery process for drug addicts. So that the government in this case the National Narcotics Agency and the Ministry of Social Affairs that have program policies and drug abuse rehabilitation budgets can work together.

The rehabilitation phase of drug addicts needs to be continued with the implementation of addictive empowerment programs, namely counseling, comparative studies, training, mentoring, and the formation of business groups based on interests and talents or potential of addicts for welfare and independence and accelerating acceptance or re-socialization with families and communities as social rehabilitation.

\section{References}

Anwar, K. (2014). Penggunaan Konseling religi sebagai pendekatan pendidikan informal Islam Dalam Mengatasi Psikopatologi Siswa di Madrasah Aliyah Islamiyah Senori Tuban, Jurnal Kependidikan Islam, 4(2), 308-333.

Babaie, E., \& Razeghi, N. (2013). Comparing the Effects of Methadone Maintenance Treatment, Therapeutic Community, and Residential Rehabilitation on Quality of Life and Mental Health of Drug Addicts. Addict Health, 5(1), 16-20.

Corey, G. (2000). Theory and Practice of Counseling and Psychotherapy, 6rd ed. Brooks Cole: Publising Company.

Darokah, D., \& Safaria, T. (2005) Perbedaan Tingkat Religiusitas, Kecerdasan Emosi, dan Keluarga Harmonis pada Kelompok Pengguna NAPZA dengan Kelompok Non-Pengguna, Humanitas: Indonesian Psychological Journal, 2(2), 89-101. https://doi.org/10.26555/humanitas.v2i2.318

Erhamwilda. (2009). Bimbingan dan Konseling religi sebagai pendekatan pendidikan informal Islami. Yogyakarta: Graha Ilmu.

Falah, R.Z. (2016). Membentuk Kesalehan Individual dan Sosial Melalui Konseling religi sebagai pendekatan pendidikan informal Multikultural”, Konseling religi sebagai pendekatan pendidikan informal: Jurnal Bimbingan Konseling Religi, 7(1), 163-188. https://doi.org/10.21043/kr.v7i1.1666

Hamid, H., \& Saebani, B. A. (2013). Pendidikan Karakter Perspektif Islam. Bandung: Pustaka Setia 
Hawari, D. (2006). Penyalahgunaan dan Ketergantungan NAZA: Narkotika, Alkohol, dan Zat adiktif. Jakarta: Gaya Baru.

Hefni, H. (2014). Perkembangan Ilmu Konseling Islam. Jurnal Konseling Islam, 4(2), 326-343.

Hermawan, A. A., \& Santosa, D. W. (2013). Penyuluh dan Pengenalan Bahaya Narkoba sebagai Bentuk Pencegahan Dini Penggunaan Narkoba pada Anak, Jurnal Inovasi dan Kewirausahan, 2(3), 178-182.

Irfangi, M. (2015). Implementasi Pendekatan Religius dalam Rehabilitai Korban Penyalahgunaan Narkoba di Rumah Sakit Khusus Jiwa H. Mutajabah Purbalingga. Jurnal Kependidikan, 3(2), 70-88. https://doi.org/10.24090/jk.v3i2.900

Keen, J., Oliver, P., Rowse, G., \& Mathers, N. (2001). Residential rehabilitation for drug users: a review of 13 months' intake to a therapeutic community. Family Practice, 18(5), 545-548. https://doi.org/10.1093/fampra/18.5.545

Kibtyah, M. (2015). Pendekatan Bimbingan dan Konseling bagi Korban Pengguna Narkoba. Jurnal Ilmu Dakwah, 35(1), 52-77. https://doi.org/10.21580/jid.v35.1.1252

Klonaris, C., Katsargyris, A., Papapetrou, A., Vourliotakis, G., Tsiodras, S., Georgopolous, S., Giannopolulos., \& Boastounis, E., (2007). Infected femoral artery pseudoaneurysm in drug addicts: The beneficial use of the internal iliac artery for arterial reconstruction. Journal of Vascular Surgery, 45(3), 498-504. https://doi.org/10.1016/j.jvs.2006.11.014

Lindesmith, A. R. (2017). Addiction and Opiates. New York: Routledge

Martono, L. H., \& Joewana, S. (2008) Belajar Hidup bertanggung Jawab, Menangkal Narkoba dan Kekerasan, Jakarta: Balai Pustaka

Notoatmodjo, S. (2008). Kesehatan dan Pembangunan Sumber Daya Manusia. Journal Kesehatan Masyarakat Nasional, 2(5), 195-199

Padmiati, E., \& Kuntari, S. (2011). Forum Rehabilitasi Berbasis Masyarakat (RBM) Dharma Kerthi Praja Pascima. Model Pemberdayaan Masyarakat dalam Penanggulangan Penyalahgunaan NAPZA di Kota Denpasar Propinsi Bali. Sosiokonsepsia, 16(2), 143-160

Platt, J. J. (1995). Vocational rehabilitation of drug abusers. Psychological Bulletin, 117(3), 416-433. https://doi.org/10.1037/0033-2909.117.3.416

Pransiska, T. (2016). Konsep Fitrah dalam Perspektif Islam dan Implikasinya terhadap Pendidikan Islam Kontemporer, Jurnal Ilmiah Didaktika, 17(1), 1-17. https://doi.org/10.22373/jid.v17i1.1586

Rahmadona, E., \& Agustin, H. (2014). Faktor yang Berhubungan dengan Penyalahgunaan Narkoba di RSJ Prof. HB. Sa'anin, Jurnal Kesehatan Masyarakat Andalas, 8(2), 59-65. https://doi.org/10.24893/jkma.8.2.6066.2014

Rahmawati, R. F. (2016). Konseling Budaya Pesantren (Studi Deskriptif Terhadap Pelayanan Bimbingan Konseling Bagi Santri Baru). Konseling Religi, 7(1). https://doi.org/10.21043/kr.v7i1.1359

Risdawati. (2014). Upaya Bimbingan Konseling religi sebagai pendekatan pendidikan informal Islam dalam Mengatasi Perilaku Menyimpang. Hikmah, 8(2),74-87

Sulaiman, A. I. (2011). Konstruksi Makna Dampak Media Internet Penggunaan Media Internet oleh Pelajar di Kota Purwokerto Kabupaten Banyumas: Studi Deskriptif Kualitatif Para Pelajar di Kota Purwokerto Kabupaten Banyumas, Jurnal Penelitian Komunikasi, 14(1), 53-62. https://doi.org/10.20422/jpk.v14i1.168

Sulaiman, A. I. (2013). Model Komunikasi Formal Dan Informal Dalam Proses Kegiatan Pemberdayaan Masyarakat. Jurnal Penelitain Komunikasi, 16(2), 173-188. https://doi.org/10.20422/jpk.v16i2.38

Widodo, A., Waridin, dan Maria, K. J. (2011). Analisis Pengaruh Pengeluaran Pemerintah Di Sektor Pendidikan Dan Kesehatan Terhadap Pengentasan Kemiskinan Melalui Peningkatan Pembangunan Manusia Di Provinsi Jawa Tengah. Jurnal Dinamika Ekonomi Pembangunan, 1(1), 25-42. https://doi.org/10.14710/jdep.1.1.25-42

Winkelman, M., (2003). Complementary Therapy for Addiction: "Drumming Out Drugs". American Journal of Public Health, 93(4), 647-651

Yin, R. K. (2013). Studi Kasus Desain dan Metode. Depok: RajaGrafindo Persada

Zulamri, Z. (2017). Pola Rehabilitasi Islami Bagi Pecandu Narkoba di Badan Narkotika Nasional Provinsi Riau: Perspektif Konseling Islam. Jurnal Dakwah Risalah, 28(1), 25-30 


\section{Copyrights}

Copyright for this article is retained by the author(s), with first publication rights granted to the journal.

This is an open-access article distributed under the terms and conditions of the Creative Commons Attribution license (http://creativecommons.org/licenses/by/4.0/). 